\title{
Sorption and Desorption of Cd(II) at the Clay Particle-Water Interface and its Relevance to the Distribution of Metal Ions in Natural Systems
}

\author{
José L. Westrup, Maurícia B. Fritzen, Aloísio J. Souza, Gizelle C. Bedendo, \\ Faruk Nome and Haidi D. Fiedler* \\ Departamento de Química, Universidade Federal de Santa Catarina, 88040-900 Florianópolis - SC, Brazil
}

\begin{abstract}
O estudo da sorção e dessorção de Cd(II) na interface de vários sorventes e soluções aquosas mostrou que a capacidade de troca depende do tipo de sorvente, do pH e do sistema tampão. Tampões como succinato e citrato, os quais são bons complexantes de Cd(II) suprimem completamente a incorporação dentro dos diferentes sorventes. Na presença do tampão Tris, a capacidade de troca observada decresce na seguinte ordem, $\gamma$-alumina $>$ montmorilonita $>$ caolinita $\approx$ sílica. A precipitação de $\mathrm{Cd}(\mathrm{II})$ torna-se importante na presença de bicarbonato aquoso na faixa de $\mathrm{pH}$ 5,5-7. As isotermas observadas para as diferentes argilas mostram saturação em concentração bastante altas de $\mathrm{Cd}(\mathrm{II})$. Isto sugere que em águas naturais, a sorção e distribuição de Cd(II) entre as fases geoquímicas dos sedimentos deve seguir uma relação linear. A cinética de dessorção de $\mathrm{Cd}$ (II) da superfície da montmorilonita, na presença do íon citrato, mostra que este é um ligante orgânico eficiente para remover o Cd(II) ligado em sítios facilmente acessíveis. O processo ocorre em duas etapas, com liberação inicial de aproximadamente $70 \%$ do Cd(II), seguido pela liberação lenta do metal de sítios com acesso controlado pela difusão.
\end{abstract}

The sorption and desorption of $\mathrm{Cd}$ (II) that occurs at the interface between several sorbents and aqueous solutions has been investigated and it is shown that the observed exchange capacity depends on the type of sorbent, the $\mathrm{pH}$ and the buffering system. Buffers such as succinate and citrate, which are good complexants of Cd(II) completely supress its incorporation into the different sorbents. In the presence of Tris buffer the observed exchange capacity decreases in the order $\gamma$-alumina $>$ montmorillonite $>$ kaolinite $\approx$ silica, while precipitation is important in the presence of aqueous bicarbonate in the $\mathrm{pH}$ range 5.5-7. The sorption data fit with general purpose isotherms well, and the sorption isotherm shows saturation at rather high concentrations of $\mathrm{Cd}$ (II) in both clays. This suggests that under many experimental conditions in natural waters, the sorption and distribution of $\mathrm{Cd}$ (II) between geochemical phases of sediments should follow a linear relationship. The kinetics of desorption from montmorillonite, in the presence of citrate ion, is particularly important, showing that this efficient organic ligand removes all the $\mathrm{Cd}$ (II) bound to readily accessible sites in a fast step, while removal of $\mathrm{Cd}$ (II) from sites with diffusion-restricted access is much slower.

Keywords: cadmium(II), Langmuir isotherms, sediments, metal distribuition

\section{Introduction}

Conceptual models have been proposed in order to interpret the distribution or partitioning of metal or trace metals in phases of sediments or minerals in aqueous solutions. ${ }^{1-3}$ Metals are known to concentrate in sediments of natural aquatic systems and this accumulation is postulated to be caused by adsorption processes with various geochemical phases such as hydrous metal oxides, clays, and organic matter. ${ }^{1,4-6}$ Biovailability to sedimentingesting organisms and release of metals to the water column in the environment depends strongly on the geochemical phase which a metal is associated. ${ }^{1-3}$

This is a complex situation since, in the field, natural

\footnotetext{
*e-mail: fiedler@qmc.ufsc.br
}

mineral surfaces are often coated with thin layers of precipitates, such as iron or manganese oxides, organic matter, and microbial biofilms. This level of complexity is difficult to study at the atomic scale under reactive conditions. ${ }^{7}$ The coating may, however, partially inhibit dissolution, thus contributing to the laboratory/field-rate discrepancies. ${ }^{8}$

Furthermore, while in the laboratory inorganic complexation reactions reach equilibrium quickly, some sorption and desorption processes of metal ions at surfaces may be slower and sometimes diffusion limited, reflecting differences in concentration and chemistry of natural water processes. Thus, in many adsorption reactions of trace metals onto particles there is a slow incorporation of the adsorbed metal into the solid matrix, and true equilibrium is not always reached. ${ }^{3,6,9}$ 
For these reasons, we examined the behaviour of $\mathrm{Cd}(\mathrm{II})$, one of the most toxic non-radioactive elements, which appears in the environment as a result of a variety of industrial processes. We report studies of sorption designed to extend our understanding of the factors that control the availability of $\mathrm{Cd}$ (II) in the environment. We selected modified montmorillonite adsorbents in order to get a closer idea of the effective processes in a natural sample.

The sorbents selected were hydrated oxides and aluminosilicates, which are ubiquitous in the aqueous environment, where their surface physico-chemical properties affect and control a variety of phenomena, including dissolution, precipitation, and sorption processes. Thus, the interaction of aqueous solutions with such surfaces affects the mobility of heavy metal contaminants, ${ }^{7,10-12}$ and clearly depends on a variety of factors, including $\mathrm{pH}$, temperature, the nature and concentration of ligands and complexing ions, the type of sorbents present, ageing of the substrate and the residence time of the metal ion at the surface and temperature. ${ }^{6,13-19}$

Thus, this work examines the adsorption and desorption of $\mathrm{Cd}$ (II) onto and from modified montmorillonite, kaolinite and hydrated oxides. Since cost-effective remediation strategies are heavily dependent on the kinetics of the involved reactions, it is important to obtain reliable kinetic data to predict the transport and fate of contaminants, as well as the kinetics of the desorption process.

\section{Experimental}

\section{Instrumentation and methods}

Spectrophotometric measurements were carried out at $25.0 \pm 0.1^{\circ} \mathrm{C}$, in the water-jacketed cell compartments of both HP-8453 diode array and Shimadzu UV-210A spectrophotometers, which were calibrated with NIST traceable UV/Vis reference materials. Surface tension measurements were carried out using of a surface tensiometer and the drop weight method.

The $\mathrm{pH}$ was measured with a Beckman model $\Phi 71 \mathrm{pH}$ meter. The glass electrode was calibrated against standard buffers, in a thermostatted stirred vessel, at a temperature of $25.0 \pm 0.1^{\circ} \mathrm{C}$. The $\mathrm{pH}$ of the buffers was adjusted to the desired value with $\mathrm{NaOH}$.

In all the sorption and desorption experiments, the $\mathrm{Cd}$ (II) concentration was determined by following the fast formation of a 1:3 complex between $\mathrm{Cd}(\mathrm{II})$ and dithizonate anion, in the presence of non ionic surfactants, ${ }^{20}$ by mixing $1 \mathrm{~mL}$ of the filtered sample with $2 \mathrm{~mL}$ of $3.0 \mathrm{~mol} \mathrm{~L}^{-1} \mathrm{NaOH}$ and $2 \mathrm{~mL}$ of an aqueous solution of Triton X-100 5\% containing $3.0 \times 10^{-4} \mathrm{~mol} \mathrm{~L}^{-1}$ dithizone. The sample was made up to a final volume of $10 \mathrm{~mL}$ and the absorbance of the samples determined at $549 \mathrm{~nm}$.

\section{Materials}

A standard solution of cadmium $\left(1.0 \mathrm{mg} \mathrm{mL}^{-1}\right)$ was prepared by dissolving $\approx 1.0 \mathrm{~g}$ pure cadmium p.a. (Vetec) in $1000 \mathrm{~mL}$ water, containing $2 \%$ of concentrated $\mathrm{HNO}_{3}$ (nitric acid $70 \%$ Carlo Erba). Calibration solutions were prepared daily by appropriate dilution of metal stock solutions and all the analytical procedures were done in a laminar flux hood (TROX ${ }^{\circledR}-100$ class).

The non-ionic surfactant Triton X-100 (Sigma) was the best available reagent grade and purified as described elsewhere. ${ }^{21}$ Surface tension $v s$. concentration measurements showed no minima. ${ }^{21}$

Doubly de-ionized water with conductivity less than 17.3 $\mathrm{mS} \mathrm{cm}$, obtained from a Nanopure ${ }^{\mathrm{TM}}$ Analytical Deionization System (type D-4700) was used to prepare the standard solutions and reagents. All vessels in contact with samples or reagents were cleaned by soaking in $5.8 \mathrm{~mol} \mathrm{~L}^{-1} \mathrm{HNO}_{3}$ (overnight) and rinsed repeatedly with de-ionized water before use.

\section{Preparation and characterization of sorbents}

Natural kaolinite was obtained from Colorminas, Brazil, and a sample of $\mathrm{Na}^{+}$-homocationic kaolinite was prepared by dispersing the fine fraction in an aqueous solution containing $\mathrm{NaCl}\left(1.0 \mathrm{~mol} \mathrm{~L}^{-1}\right)$ in Nalgene vessels. After $24 \mathrm{~h}$ of shaking at room temperature, in a Dubnoff type water bath, the suspension was filtered through $0.45 \mathrm{~mm}$ Schleicher \& Schuell filter membranes and the samples subjected to the same procedure four times, following the procedure for the preparation of clay minerals loaded with monovalent $\mathrm{Na}^{+}{ }^{18}$ As usual, the $\mathrm{Na}^{+}$-saturated clay was washed with distilled water until chloride ion was no longer detected by means of $\mathrm{AgNO}_{3}$ addition. Samples of silica, $\gamma$-alumina and montmorillonite KSF (enriched with Fe(III)), were obtained from Sigma-Aldrich.

\section{Sorption experiments}

The background electrolyte solution consisted of 0.10 mol L $\mathrm{L}^{-1}$ Tris buffer, $\mathrm{pH} 7.0$; this does not interfere with metal sorption under our experimental conditions. At the start of the sorption experiment $25 \mathrm{~mL}$ of $\mathrm{Cd}$ (II) were added to $1 \mathrm{~g}$ of adsorbent and the mixture was kept at $25^{\circ} \mathrm{C}$ in a Dubnoff type water bath, at a reciprocal shaking speed of $120 \mathrm{rpm}$, for $24 \mathrm{~h}$. The solution was filtered through a 0.45 $\mu \mathrm{m}$ (Schleicher \& Schuell filter membranes) and the solution then analyzed as previously described. The 
amount of Cd(II) sorbed was calculated from the difference between the initial and final Cd(II) concentration.

\section{Desorption experiments}

Desorption experiments were carried out after an initial incubation time of $24 \mathrm{~h}$ under conditions similar to those described above. The desorption was started by adding 25 $\mathrm{mL}$ of a background electrolyte consisting of $0.10 \mathrm{~mol}$ $\mathrm{L}^{-1}$ citrate buffer and the suspensions were kept at $25^{\circ} \mathrm{C}$ in the same thermostatted bath and under the same conditions described for the sorption experiments. The citrate buffer effectively complexes all the desorbed $\mathrm{Cd}(\mathrm{II})$ ion, preventing back adsorption of the metal on to the clay surface (see Results and Discussion). Samples collected at different times were filtered through $0.45 \mu \mathrm{m}$ membranes and the desorbed $\mathrm{Cd}(\mathrm{II})$ ion determined as described above.

\section{Results and Discussion}

The surfaces of materials such as alumina, silica, kaolinite and montmorillonite have electric charge densities which depend on $\mathrm{pH}$ and composition of the surface, which in turn need to be counterbalanced in the aqueous solutions in order to maintain the electroneutrality of the solution. Thus, an electrical double layer is generated at the sorbent/water interface and this interaction is important for the adsorption of different metal ions. As should be expected, the adsorption and desorption of the metals depends strongly on the nature of the sorbent and on the concentration of chemical species present in solution, which can act as complexants to promote desorption or enhance sorption of the metal ion. ${ }^{9,12}$

Since Cd(II) ions slowly precipitate at $\mathrm{pH}$ 7.0, buffers were selected in order to avoid precipitation, which would affect the adsorption studies. As shown in Figure 1, the selection of buffer proved to be crucial: in the presence of bicarbonate, precipitation is observed as a function of $\mathrm{pH}$ in the range 5.5 to 7.0 , with precipitation relatively fast at $\mathrm{pH}$ 7.0. Addition of $0.10 \mathrm{~mol} \mathrm{~L}^{-1}$ Tris buffer completely prevented precipitation at $\mathrm{pH} 7.0$ over a period of 30 days. This is the expected result of the formation of a 1:1 complex between Tris and $\mathrm{Cd}$ (II) (stability constant $\log \mathrm{K}=1.88$ at $25{ }^{\circ} \mathrm{C}$ ). ${ }^{22}$ Similar results were obtained in the presence of added 0.10 mol L ${ }^{-1}$ citrate buffer, which also forms a 1:1 complex (log K $=3.1)^{22}$ and of added $0.10 \mathrm{~mol} \mathrm{~L}^{-1}$ succinate which forms complexes with different stoichiometries $(\log \mathrm{K}=3.38$ for the complex with a $1: 3 \mathrm{Cd}$ (II) to succinate molar ratio). ${ }^{22}$

Figure 2 shows the results obtained for the adsorption of $\mathrm{Cd}(\mathrm{II})$ on alumina, silica, and two important clay minerals (montmorillonite and kaolinite) at $\mathrm{pH} 7.0$ and $25^{\circ} \mathrm{C}$, in the presence of different buffers. As can be seen, the sorption of

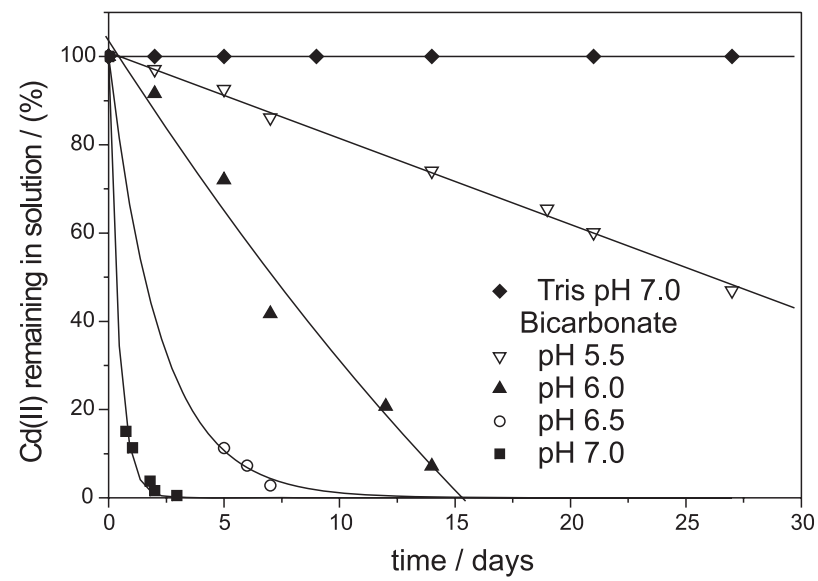

Figure 1. Precipitation kinetics of $\mathrm{Cd}(\mathrm{II})$ in the presence of 0.10 mol $\mathrm{L}^{-1}$ Tris or sodium bicarbonate as a function of $\mathrm{pH}$, at $25.0{ }^{\circ} \mathrm{C}$.

$\mathrm{Cd}(\mathrm{II})$ on the different sorbents, in the presence of $0.10 \mathrm{~mol}$ $\mathrm{L}^{-1}$ Tris buffer, show a similar behavior, except in relation to the amount of $\mathrm{Cd}$ (II) sorbed in each clay for a particular metal ion concentration. Visual examination indicates that the data are consistent with previous reports: as expected, montmorillonite shows a higher exchange capacity, which appears as higher sorption values than those observed for kaolinite. Alumina proved to be the best of the sorbents, with silica and kaolinite being the least effective materials in removal of $\mathrm{Cd}(\mathrm{II})$ from solution.

The results are readily rationalised. It is well known that kaolinite has a minimal permanent negative charge, and that $\mathrm{Cd}$ is probably sorbed on its edges (though not much at $\mathrm{pH}$ 7). When montmorillonite is used as the sorbent, there are both edge sites and planar cation-exchange sites. These latter take part in cation exchange reactions and the binding of trace metals at these sites depends on the concentrations of other major ions present. In order to have a sample of similar

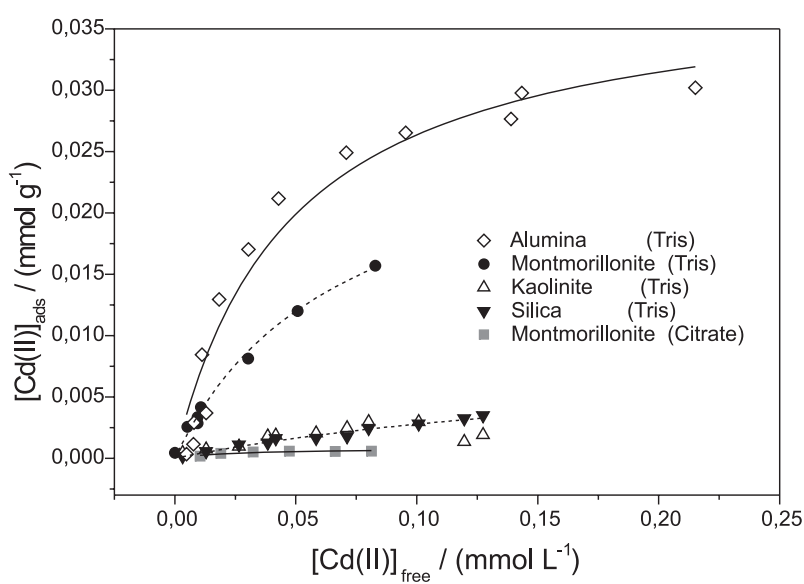

Figure 2. $\mathrm{Cd}(\mathrm{II})$ adsorption isotherms measured at $25.0{ }^{\circ} \mathrm{C}$ and at $\mathrm{pH} 7.0$, for $\gamma$-alumina, silica and kaolinite samples in the presence of $0.10 \mathrm{~mol} \mathrm{~L}^{-1}$ Tris buffer and for montmorillonite in the presence of $0.10 \mathrm{~mol} \mathrm{~L}^{-1}$ Tris buffer and $0.10 \mathrm{~mol} \mathrm{~L}^{-1}$ citrate buffer. 
Table 1. Chemical compositions (\%) obtained by XRF for kaolinite, montmorillonite, aluminium oxide, silica gel and natural sediment

\begin{tabular}{|c|c|c|c|c|c|c|c|c|c|c|c|}
\hline & $\mathrm{SiO}_{2}$ & $\mathrm{Al}_{2} \mathrm{O}_{3}$ & $\mathrm{~K}_{2} \mathrm{O}$ & $\mathrm{Fe}_{2} \mathrm{O}_{3}$ & $\mathrm{CaO}$ & $\mathrm{Na}_{2} \mathrm{O}$ & $\mathrm{MgO}$ & $\mathrm{TiO}_{2}$ & $\mathrm{P}_{2} \mathrm{O}_{5}$ & $\mathrm{MnO}$ & $\mathrm{LOI}^{\mathrm{a}}$ \\
\hline Kaolinite & 46.31 & 38.90 & 1.42 & 0.73 & $\begin{array}{c}0.41 \\
(0.01)^{\mathrm{b}}\end{array}$ & 0.37 & $\begin{array}{c}0.22 \\
(0.10)^{\mathrm{b}}\end{array}$ & 0.16 & N.D. ${ }^{c}$ & N.D. ${ }^{c}$ & 11.49 \\
\hline Montmorillonite & 53.21 & 17.58 & 1.38 & 5.40 & 1.37 & 0.28 & 2.53 & 0.37 & 0.17 & 0.05 & 17.65 \\
\hline Aluminium oxide & N.D. ${ }^{b}$ & 90.70 & 0.05 & 0.03 & 0.04 & 1.93 & N.D. ${ }^{c}$ & N.D. ${ }^{c}$ & 0.12 & N.D. ${ }^{c}$ & 2.75 \\
\hline Sílica gel & 99.66 & 0.02 & 0.01 & $<0.01$ & 0.20 & 0.05 & 0.02 & 0.03 & 0.01 & $<0.01$ & 0.00 \\
\hline Natural sediment ${ }^{\mathrm{d}}$ & 54.74 & 15.37 & 2.65 & 6.01 & 1.49 & 4.37 & 2.18 & 0.83 & 0.19 & 0.14 & 12.04 \\
\hline
\end{tabular}

${ }^{a}$ LOI, loss of ignition; ${ }^{b}$ results obtained for the homocationic kaolinite; ${ }^{\mathrm{c}}$ ND, not detected; ${ }^{\mathrm{d}}$ from Sambaqui in the coastal region of Santa Catarina, Brazil; collected on 08 August, 2003.

composition to the typical sediments on Santa Catarina island (Table 1), we selected a special type of montmorillonite (KSF), rich in $\mathrm{Fe}_{2} \mathrm{O}_{3}$, (Table 1) which strongly affects the binding of $\mathrm{Cd}(\mathrm{II})$ (see below). It is important to remark that the sediments collected in the Sambaqui region were selected because the water column shows a very low Cd(II) content (ca. $0.02 \mu \mathrm{g} \mathrm{L}$ $\left.{ }^{1}\right){ }^{23}$ Although the environment is not made up of pure clay minerals, the use of appropriately selected models will provide a basis for a better understanding of the behavior expected for given compositions of natural sediments. The results obtained for montmorillonite in the presence of citrate ion are significant, in the sense that any organic ligands with a reasonably large stability constant (see above) will accumulate Cd(II) preferentially. In an aquatic environment rich in carbonates, precipitation could become the main route for incorporation of $\mathrm{Cd}(\mathrm{II})$ in the sediments. The findings described above are consistent with previous results obtained with samples of sediments from Flumendosa Lake in Italy and from Rio Besos in Spain. ${ }^{3,24}$ Since the sediments from Flumendosa Lake and Rio Besos show quite different compositions, the distribution of $\mathrm{Cd}(\mathrm{II})$ between the different fractions of the sequential extraction procedure follows closely the change in composition and, therefore, different contents of $\mathrm{Cd}(\mathrm{II})$ are found associated to each of the fractions. ${ }^{3,24}$ Clearly, the composition of the different geochemical fractions of the sediment, are determinant for the $\mathrm{Cd}(\mathrm{II})$ distribution in sediments. As would be expected from the XRF analysis shown in Table 1 and consistent with the discussion above, the natural sediment collected from Sambaqui in the coastal region of Santa Catarina shows a behaviour essentially identical to montmorillonite.

The adsorption data in Figure 2 were fitted to several general-purpose isotherms ${ }^{14}$ by means of a non-linear least squares program and the quality of the fits was compared with the standard Langmuir isotherm on the basis of the square of the correlation coefficient $\left(\mathrm{r}^{2}\right)$. Although in the following discussion results are treated in terms of adsorption isotherms, most probably cation exchange reaction with a sorption component are responsible for the chemical processes in the solution sorbent interphase.

The sorption data were initially evaluated with
Langmuir, Redlich-Petersen, Toth and LangmuirFreundlich isotherms (equations 1-4, respectively).

$\mathrm{n}=\mathrm{KcM} /(1+\mathrm{Kc})$

$\mathrm{n}=\mathrm{Kc} \mathrm{M} /\left(1+(\mathrm{Kc})^{\beta}\right)$

$\mathrm{n}=\mathrm{KcM} /\left(1+(\mathrm{Kc})^{\beta}\right)^{1 / \beta}$

$\mathrm{n}=(\mathrm{Kc})^{\beta} \mathrm{M} /\left(1+(\mathrm{Kc})^{\beta}\right)$

In all cases, $\mathbf{n}$ corresponds to the amount adsorbed per gram of clay (mmol/g clay); $\mathrm{K}$ is corresponds to the adsorption equilibrium constant and $\mathbf{c}$ the equilibrium solution concentration of the metal ion; $\mathrm{M}$ represents the maximum adsorption (mmoles/g clay); and $\beta$ describes the heterogeneity of the surface..$^{14}$ It is important to remark that, while the Langmuir isotherm fitted adequately all the data, the results obtained with the other general purpose isotherms were less satifactory, showing either values of $\beta=1$ (for alumina and montmorillonite) or could not get adequate convergency in the non-linear regression analysis (silica and kaolinite). Since, the Redlich-Petersen, Toth and Langmuir-Freundlich isotherms are simplified to the form of the Langmuir isotherm when $\beta=1$, all the comparisons were done using the Langmuir isotherm and are given in Table 2. It can be seen that despite the fact of being highly enriched in Fe(III), the maximum adsorption observed for montmorillonite is significantly higher than that of kaoilinite, a result consistent with the higher exchange capacity of this clay. It is interesting to observe that the concentration of free $\mathrm{Cd}$ (II) ions needed to saturate the montmorillonite surface is rather high in terms of environmental conditions, a result which indicates that in most conditions prevalent in natural waters, the distribution of metal between the different geochemical phases of the sediment should follow a simple linear relationship., ${ }^{3,25}$ As expected, at very high metal concentration, the linear behavior breaks down.

The observed results are indicative of a maximum binding for montmorillonite of about $0.028 \mathrm{mmol} \mathrm{g}^{-1}$ or 5.6 meq/100g (Figure 2), much lower than the value expected 
Table 2. Langmuir isotherm parameters for adsorption of $\mathrm{Cd}(\mathrm{II})$ on different sorbents

\begin{tabular}{lcccc}
\hline \multirow{2}{*}{ Sorbent } & Buffer & \multicolumn{2}{c}{ Langmuir Isotherm Parameters } \\
\cline { 3 - 5 } & & $\mathrm{K}$ & $\mathrm{M}$ & $\mathrm{R}^{2}$ \\
& & $\left(\mathrm{~L} \mathrm{mmol}^{-1}\right)$ & $\left(\mathrm{mmol} \mathrm{g}^{-1}\right)$ & \\
\hline Aluminium oxide & Tris & 20.8 & 0.039 & 0.949 \\
Montmorillonite & Tris & 14.8 & 0.028 & 0.990 \\
Montmorillonite & Citrate & 51.7 & $7.6 \times 10^{-4}$ & 0.881 \\
Kaolinite & Tris & 4.3 & 0.014 & 0.906 \\
Silica & Tris & 3.0 & 0.012 & 0.972 \\
\hline
\end{tabular}

for montmorillonite (CEC about $100 \mathrm{meq} / 100 \mathrm{~g}$ ). Clearly, the high concentration of $\mathrm{Fe}$ (III) present uses the available sites and, therefore, affects the distribution of metals in the sediment. The selectivity order and the binding capacity follow the order, $\gamma$-alumina $>$ montmorillonite $>$ kaolinite $\approx$ silica, a result which is strongly indicative that aluminum sites are fundamental for the binding of $\mathrm{Cd}(\mathrm{II})$.

When the adsorption experiments were run in the presence of $0.10 \mathrm{~mol} \mathrm{~L}^{-1}$ citric acid/citrate buffer, basically all the metal ion remained in solution and the sorption of $\mathrm{Cd}(\mathrm{II})$ on to montmorillonite decreased more than 60 -fold (Figure 2: kaolinite showed similar behavior). Since citric acid complexes $\mathrm{Cd}$ (II) with a reasonably high stability constant $\left(\log \mathrm{K}=3.66\right.$ at $\left.25^{\circ} \mathrm{C}, \mu=0.1\right)$ the decrease in sorption is related to the decrease in free metal ion in solution, and this capability of the complexant to retain $\mathrm{Cd}(\mathrm{II})$ in solution allowed the study of the desorption of $\mathrm{Cd}(\mathrm{II})$ from the clay surfaces.

\section{Desorption of $C d(I I)$ from montmorillonite and kaolinite}

Figure 3 shows the desorption process of $\mathrm{Cd}(\mathrm{II})$ from montmorillonite and kaolinite samples. While the desorption of $\mathrm{Cd}(\mathrm{II})$ from kaolinite is fast and quantitative, montmorillonite shows a fast release of $70 \%$ of the sorbed $\mathrm{Cd}(\mathrm{II})$ followed by a slow process which reaches equilibrium after some $400 \mathrm{~min}$. In order to treat the desorption data of the slow process we used a kinetic treatment based on a single site-type (equation 5), ${ }^{16}$

$\left(\mathrm{d}\left(\mathrm{n}_{\mathrm{o}}-\mathrm{n}_{\mathrm{d}}\right) / \mathrm{dt}\right)=-\mathrm{k}_{\mathrm{d}}\left(\mathrm{n}_{\mathrm{o}}-\mathrm{n}_{\mathrm{d}}\right)+\mathrm{k}_{-\mathrm{d}} \mathrm{n}_{\mathrm{d}} \mathrm{C}$

where $n_{o}$ and $n_{d}$ correspond to the initial concentration of $\mathrm{Cd}(\mathrm{II})$ adsorbed in the clay and the quantity liberated at any time $\mathrm{t}\left(\mathrm{mmoles}^{-1}\right)$, respectively. $\mathrm{C}$ is the concentration of free $\mathrm{Cd}(\mathrm{II})$ in the reaction mixture at time $\mathrm{t}$ and the constants $\mathrm{k}_{\mathrm{d}}$ and $\mathrm{k}_{\mathrm{d}}$ represent the desorption mass transfer coefficient $\left(\mathrm{s}^{-1}\right)$ and the reverse (adsorption) mass transfer coefficient (L mmol $^{-1} \mathrm{~s}^{-1}$ ), respectively. ${ }^{16}$ It is important to remark that the presence of citrate in solution allows a significant

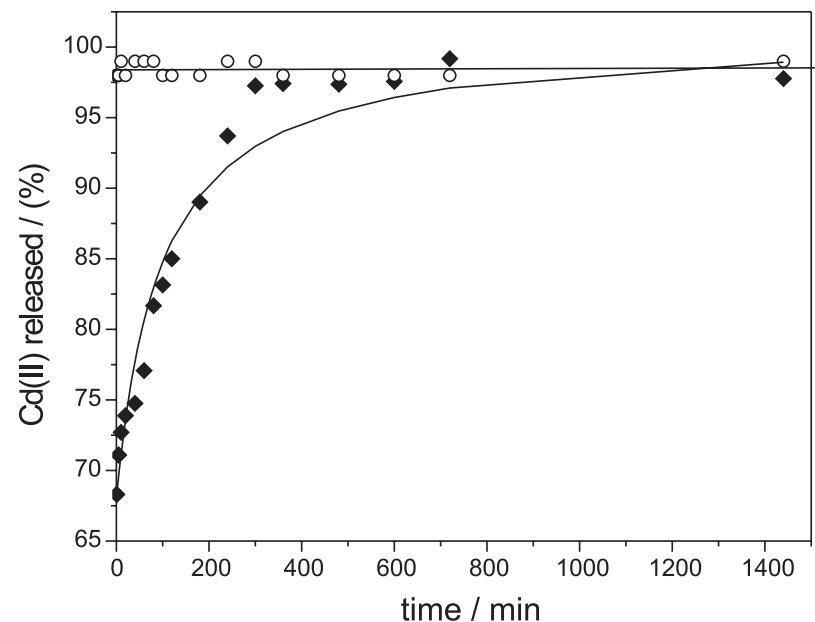

Figure 3. Desorption of $\mathrm{Cd}(\mathrm{II})$ at $25.0{ }^{\circ} \mathrm{C}$ and $\mathrm{pH} 7.0$, in the presence of $0.10 \mathrm{~mol} \mathrm{~L}^{-1}$ citrate buffer for montmorillonite $(\bullet)$ and kaolinite $(O)$ samples.

simplification of the data treatment. Indeed, by complexing and, therefore, removing free $\mathrm{Cd}$ (II) ion, the added citrate drives the desorption forward, and back reactions are eliminated. The adsorption isotherms contained in Figure 2 are consistent with this assumption and, clearly, the incorporation of $\mathrm{Cd}(\mathrm{II})$ in either kaolinite or montmorillonite is insignificant in the presence of citrate ion.

These experimental observations allow us to simplify equation 5 by eliminating the reverse reaction, and the integrated form corresponds to a typical first order process (equation 6).

$\ln \left(\left(\mathrm{n}_{\mathrm{o}}-\mathrm{n}_{\mathrm{d}}\right) / \mathrm{n}_{\mathrm{o}}\right)=-\mathrm{k}_{\mathrm{d}} \mathrm{t}$

Treatment of the data in Figure 3, using linear regression analysis, allowed the calculation of a value of $\mathrm{k}_{\mathrm{d}}=(9.7 \pm 0.7)$ $\mathrm{x} 10^{-5} \mathrm{~s}^{-1}$, with a correlation coefficient $\rho=0.985$. Clearly, the small value of the standard deviation and the value of $\rho$ indicate the suitable fit of the data in Figure 3. The observed kinetic desorption profile is similar to those reported for the desorption of $\mathrm{Pb}$ (II) from $\gamma-\mathrm{Al}_{2} \mathrm{O}_{3}$, by both the replenishment method and the product-removal technique. The biphasic behavior shows that in the first few minutes about $70 \%$ of the $\mathrm{Cd}(\mathrm{II})$ ion is removed and after 24 hours the resulting recovery is about $99 \%$. Clearly the fast step of the observed kinetic behavior must be the desorption from readily available sites on the surface of montmorillonite, while the slow process must correspond to the release of $\mathrm{Cd}(\mathrm{II})$ from sites on the interior of the solid clay, via either a pore diffusion model or a homogeneous solid phase diffusion model. It is important to remark that the slow release of $\mathrm{Cd}$ (II) was not observed in the experiments with kaolinite, where about $98 \%$ was released from the clay in the first $30 \mathrm{~min}$. The desorption kinetics are consistent with the physical data, since montmorillonite, 
compared to kaolinite, has a highly microporous structure, with a large number of Si sites exposed to the solution due to its interlayer expansion: these account for $97 \%$ of the available sites in the montmorillonite clay. ${ }^{26}$

\section{Conclusions}

The study of the sorption and desorption of $\mathrm{Cd}(\mathrm{II})$ from the surface of $\gamma$-alumina, montmorillonite, kaolinite and silica are considerably facilitated by the use of an analytical procedure using the nonionic surfactant Triton X-100. In both clays, the sorption isotherm shows saturation at rather high concentrations of $\mathrm{Cd}(\mathrm{II})$, a fact which suggests that in many experimental conditions in natural waters, sorption and distribution of $\mathrm{Cd}$ (II) between geochemical phases of similar nature to clays, should follow a linear relationship. The experimental results are strongly indicative that the distribution of $\mathrm{Cd}(\mathrm{II})$ between the different fractions of sequential extraction procedures follows the change in composition of the matrix and, therefore, the composition of the different geochemical fractions of the sediment can be considered to be determinant for the distribution of metal ions in sediments. It is important to remark that the success of the application of this type of model based on adsorption isotherms, in terms of prediction of metal distribution, depends heavily on the experimental conditions and good agreement is expected only under similar $\mathrm{pH}$ regimes. The kinetics of the desorption from montmorillonite, in the presence of citrate ion, is particularly important since this efficient organic ligand removes all the $\mathrm{Cd}$ (II) bound to readily accessible sites in a fast step, while removal of $\mathrm{Cd}$ (II) from sites with diffusionrestricted access is much slower. Finally, the fact that $\mathrm{Cd}(\mathrm{II})$ can be leached out quantitatively from the clays rather easily, indicates that a contaminated area could pose unpredictable groundwater problems and suggests that contaminated sites could be remediated by washing with adequately selected extracting agents in aqueous solutions.

\section{Acknowledgments}

The authors are grateful to PRONEX, CNPq and Capes for financial support, and to Professor Orestes E. Alarcon of Federal University of Santa Catarina (Brazil) for the kaolinite samples.

\section{References}

1. Oakley, S. M.; Nelson, P. O.; Williamson, K.J.; Environ. Sci. Technol. 1981, 15, 474.

2. Kraepiel, A. M. L.; Keller, K.; Morel, F. M. M.; J. Colloid Interface Sci. 1999, 210, 43.
3. Nome, R. A.; Martinez, C. M.; Nome, F.; Fiedler, H. D.; Environ. Toxicol. Chem. 2001, 20, 693.

4. Gibbs, R.J.; Science 1973, 180, 71.

5. Whalley, C.; Grant, A.; Anal. Chem. Acta 1994, 291, 287.

6. Tessier, A.; Turner, D.R.,eds.; Metal Speciation and Bioavailability in Aquatic Systems, IUPAC Published by John Wiley \& Sons Ltd.: Oxford, UK, 1995.

7. Brown Jr., G. E.; Science 2001, 294, 67.

8. Nugent, M. A.; Brantley, S. L.; Pantano, C. G.; Maurice, P. A.; Nature 1998, 395, 588.

9. Stumm, W.; Morgan, J.J.; Aquatic Chemistry. Chemical Equilibria and Rates in Natural Waters. $3^{\text {rd }}$ ed., John Wiley \& Sons, Inc.: NY, 1996.

10. Brown Jr., G. E; Henrich, V. E.; Casey, W. H.; Clark, D. L.; Eggleston, C.; Felmy, A.; Goodman, D. W.; Grätzel, M.; Maciel, G.; McCarthy, M. I.; Nealson, K. H.; Sverjensky, D. A.; Toney, M. F. ; Zachara, J. M.; Chem. Rev. 1999, 99, 77.

11. Attard, G.; Barnes, C.; Surfaces, Oxford University Press Inc.: U.K., Chapter 1, 2001.

12. Stumm, W.; Chemical Processes at the Particle-Water Interface, John Wiley \& Sons, Inc.: NY, 1987.

13. Altin, O.; Ozbelge, O.; Dogu, T.; J. Colloid Interface Sci. 1998, 198, 130.

14. Kinniburgh, G. D.; Environ. Sci. Technol. 1986, 20, 895.

15. McKay, G.; Bino, M. J.; Altememi, A.; Wat. Res. 1986, $20,435$.

16. Yin, Y.; Allen, H. E.; Huang, C. P.; Sparks, D. L.; Sanders, P. F.; Environ. Sci. Technol. 1997, 31, 496.

17. Zhang, P.; Sparks, D. L.; Environ. Sci. Technol. 1990, 24, 1848.

18. Hajjaji, M.; Kacim, S.; Alami, A.; Bouadili, A. E.; Mountassir, M. E.; Appl. Clay Sci. 2001, $20,1$.

19. Strawn, D. G.; Scheidegger, A. M.; Sparks, D. L.; Environ. Sci. Technol. 1998, 32, 2596.

20. Fiedler, H. D.; Westrup, J.L.; Souza, A. J.; Pavei, A. D.; Chagas, C. U.; Nome, F.; Talanta 2004, 64, 190.

21. Bunton, C. A.; Nome, F.; Quina, F. H.; Romsted, L. S.; Acc. Chem. Res. 1991, 24, 357.

22. NIST Standard Reference Database 46, Version 6.0, distributed by NIST Standard Reference Data: Gaithersburg, MD 20899.

23. Curtius, A. J.; Seibert, E. L.; Fiedler, H. D.; Ferreira, J. F.; Vieira, P. H. F.; Quim. Nova 2003, 26, 44.

24. Fiedler, H. D.; López-Sánchez, J. F.; Rubio, R.; Rauret, G.; Quevauviller, Ph.; Ure, A. M.; Muntau, H.; Analyst 1994, 119, 1109.

25. Nelson, Y. M.; Thampy, R. J.; Motelin, G. K.; Raini, J. A.; Di Sante, C. J.; Lion, L.W.; Environ. Toxicol. Chem. 1998, 17, 2302.23

26. Schulthess, P. C.; Huang, P. C.; Soil. Sci. Soc. Am. J. 1990, 54, 679.

Received: July 19, 2004

Published on the web: July 27, 2005 